\title{
Erratum to: Outsourcing of Housework and the Transition to a Second Birth in Germany
}

\author{
Liat Raz-Yurovich ${ }^{1}$
}

Published online: 10 March 2016

(C) Springer Science+Business Media Dordrecht 2016

\section{Erratum to: Popul Res Policy Rev DOI 10.1007/s11113-016-9384-2}

In the original publication of this article, the acknowledgement section has been missed to publish. Now the acknowledgement has been provided in this erratum.

Acknowledgments I acknowledge support from the Marie Curie Career Integration Grant (project number: 618294), under the FP7 scheme. I would also like to thank Barbara S. Okun, Michaela Kreyenfeld, Michael Shalev, Felix Roessger, Esther Geisler, and Sandra Krapf for commenting on earlier versions of this article. Special thanks are also given to Maria Beihof for research assistance.

The online version of the original article can be found under doi:10.1007/s11113-016-9384-2.

Liat Raz-Yurovich

liat.raz@mail.huji.ac.il

1 Department of Sociology and Anthropology, and the School of Public Policy, Hebrew University of Jerusalem, Jerusalem, Israel 